\title{
BIOLOGICAL ACTIVITY OF Rhizobium LIPO-POLYSACCHARIDES: A REVIEW ARTICLE
}

\author{
Raghad N. Gergees Najwa I. AL-Barhawi Shimal Y. Abdulhadi \\ University of Mosul/ College of Education for Pure Sciences/ Biology Department \\ Email: raghadnawaf@uomosul.edu.iq
}

\begin{abstract}
Lipo-polysaccharides are important substances that consist of LipidA, Core and $\mathrm{O}$-antigen, and are formed in several metabolic pathways that include nine enzymes encoded by special genes called Custer genes. These carbohydrates are characterized by many physical properties, including viscosity. It's viscosity of polysaccharides viscosity ranges from 0.0020 to 0.0033 seconds/cm2, Optical rotation,right-side dextrorotatory and levorotatory.Lipo-polysaccharides have a prominent role in many fields. In the agricultural, they contribute to the formation of root nodules on leguminous plants of great importance in nitrogen fixation processes.In addition to it's role in the processes of creation and differentiation of callus leguminous plants, such as clover, alfalfa, and non-leguminous plants, such as tobacco.As for the medical and pharmaceutical fields, it haveclear importance in the immune response processes through its presence as one of the important antigens present on the surface of bacterial cells.In addition to its role in the adhesion process leading to the formation of bacterial colonies and as barriers that prevent the penetration of anti-bacterial agents into the bacterial cell.
\end{abstract}

KeyWords: Rhizobiumm, Lipo-polysaccharide, Lipid-A, Core regin, Oantigen

Received: 3/1/2021, Accepted: 29/3/2021

\section{INTRODUCTION}

The Gram-negative bacteria possesses an internal membrane surrounded from the outside by the plasma membrane and from the inside of the cytoplasm, which plays an important role in protecting bacteria from external conditions and is the point of contact of bacteria to the outer environment, as well as its importance in various biological activities of bacteria such as movement and contact with host (Laverty,et al.,2014). This membrane is called Lipo-Polysaccharide (LPS), which is chemically synthesized from three regions: lipid-A, core, and O-antigen, the Lipid-A region is the part responsible for the association with the bacterial membrane, while core, is consists of frequent units of multiple sugars that communicate with lipid-A bya poly2-keto-3-deoxyoctulosonic(Kdo),and the third part O-antigen consist mainly of sugar units(D' Antuono et al.,2005).O-antigen is also formed in Ensifer meliloti from four repeating units of glucose amine linked together by $\beta-1,4$-linkageto form the $\mathrm{N}$ acetyl-D-glucosamine chain, carrying the sulfate group as sulfated carbohydrates responsible for choosing the right legume host for it, known for its role in suppressing plant defense systems by protecting bacteria from the full effect of phytotoxins secreted in the area around the roots (Lerouge and Vanderleyed, 2002; and Campbell et al,. 2002). Several studies have also been conducted on its use (LPS) in the field of tissue culture on some leguminous and non-leguminous plants (Tang et al.,2014). 


\section{1- The types of polysaccharides in rhizobium bacteria:}

Researchers Noel and Duelli (2000) indicated that polysaccharides exist in three forms on the outer membrane of rhizobium bacteria. Figure (1) shows these three types of sugars and their locations on the surface of rhizobium bacteria.

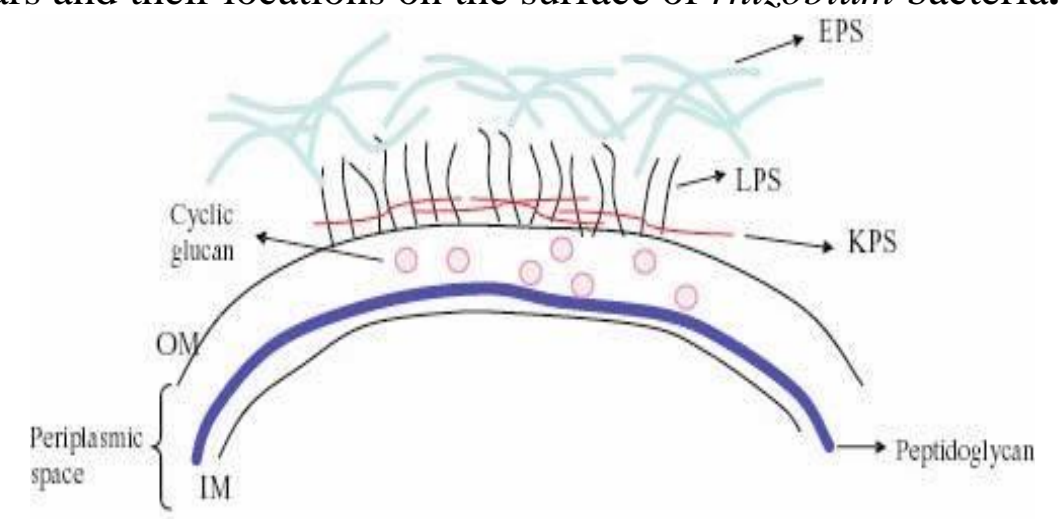

Figure (1): The three forms of polysaccharides located on the surface of rhizobium bacteria (Lepek and D'antuono, 2005).

1-1 Exopolysaccharides: It is a compound of an acidic nature outside of cellular differential composition with high molecular weights, and possesses repeating units between (7-9) of hexose sugar, and is not associated with each other by linkage glycoside bonds, furthermore having four non-carbohydrate substitutes such as succinate, pyruvate, or acetate, their acidic nature is due to the organic acids uronate, pyruvateand succinate, Pyruvy 1, units of glucose (Spaink, 2000), and (EPSII) gabctoglcan EPS, which consist of repeating units of two types of sugars, glucose and lactose, group acetyl and pyruvyl (Moreira et al., 2000). It's main function is to protect the cell from environmental stresses in addition to it's function in the association of rhizobial bacteria with the roots of leguminous plants and then in the formation of root nodes during the symbiotic relationship that results in the fixation of atmospheric nitrogen to ammonia (Fraysse et al.,2005).

1-2 Capsular polysaccharides: It's a collar that surrounds these bacteria and gives them the characteristic of resistance against bacteriophages because they contain hydrate. Which is similar to the structure of K-antigen present in Escherichia coli bacteria and that is why it is called K-antigen Polysaccharides(KPS) polysaccharide K-antigen (Sachdeva, et al, 2017), and it has an indirect role in the symbiotic relationship of Ensifer meliloti bacteria, the strain Ak31, which forms an indefinite nodule. Alfalfa plants also have a role in the sticking of bacterial cells to each other on the outer membrane (Lepek and D'Antuono, 2005).

1-3Lipo-PolySaccharides (LPS): a lipid-glycans complex, usually liberated during the normal growth cycle of the bacterium or after the death of the cell or it'sbreakdown by the host's defenses (Todar, 2002), also known as lipo-glycans or endotoxins. They are large molecules that usually consist of fats and multiple sugars that are bound together by covalent bonds. It is found in the outer membrane of the Gram-negative bacteria, and it provokes strong immune 
responses in animals. The term lipo-oligoSaccharide (LOS) is used to refer to the low molecular weight of some of it's types (Kilar et al., 2013), given that the average molecular weight of the sugar molecule poly-fatty acids are estimated at 07-106 dalton, on the other hand, many studies indicated that poly-fatty sugar is stable at boiling point for (30) minutes and that it breaks down when treated with strong oxidizing agents such as hypochlorite, superoxide, peroxide and is not digested with proteolytic enzymes (Todar, 2002), these molecule importance in bacteria is to help helping the cell membrane to be more stabilize, as well as to be a barrier against anti-bacterial compounds such as base peptides,on the other hand,it's composition varies from one strain to another (Lerouge and Venderlegden, 2002).Several researchers have found thatit has specific roles in the late stages of root nodules formation processes such as penetration of infection thread into cortical cells or of the nitrogen fixation phenotype formation (Fraysse et al., 2003).

1-4Lipo-polysaccharide structure:It is a complex compound consisting of hydrophobic and hydrophilic molecules, and it is found in all the outer membranes in the Gram-negative bacteria, and it consists of two chemically different regions, the hydrophilic region, which includes the core region, O-antigen, and the hydrophobic region is called the Lipid-A region (Raetz and Whitfield, 2002), as shown in Figure (2).

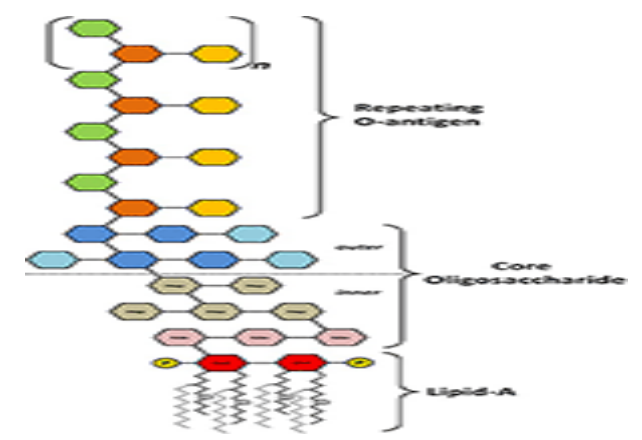

Figure (2): Chemical structure of Lipo-polysaccharide (Serrato,2014) .

1-5 O-Antigen sidechain -region:is a polymeric glucan, whose composition varies from one strain to another, and there are 160 types of it (Raetz and Whitfield, 2002). The presence or absence of this chain depends on the type of LPS, as it is present in the form of a long strain in the case of smooth LPS and is absent or reduced in the rough LPS, as it contains repeated secondary units of oligosaccharide consisting of 3-5 sugars (Rittig et al., 2003).Also, these chains may differ in their lengths exceeding 40 repeated units of sugars, so that, the Oantigen polysaccharide is longer than the sugar present in the core region, and in general, the response against the LPS is often attributed to the $\mathrm{O}$-antigen (Lerouge and Vanderleyden, 2002) because the principle antigenic in terms of antibody binding to the Gram-negative bacterial wall (Todar, 2002).

1-6 Core-Region: It is a short chain of low-unit sugars covalently attached to the site (6) of (N-acetyleglucoseamine), which in turn binds to lipid- A, noting that this core region consists of two types of unusual sugars, namely heptose Keto -3deoxy octanoic acid (Kdo), it is a distinct and exceptional compound that is permanently present in LPS, so it is positive evidence for the presence of the Core- 
region in multiple sugar tests, It is also found in all types of the same bacterial genus, but it differs morphologically between the different genus of Gramnegative bacteria such as Shigella, Escherichia, and Salmonella, and these types are similar in which the Core-region is not identical (Todar, 2002).The Coreregion of the lipo-polysaccharide in E. coli consists of five distinct structures of oligosaccharides (Amor et al., 2000).

1-7 Lipid-A Region: This region is responsible for the endotoxin in bacteria, and its chemical composition has been determined in different bacterial types, including E. coli (Figure 3), (Silipo et al.,2010 ). The core region of these bacteria was considered as the lowest structure capable of exhibiting endotoxin activities represented by the molecule containing residues of two or two groups of Dglucoseamin, two phosphorylated groups, and six fatty acids (Kato et al., 2000). Although it is stable at high temperatures in Gram-negative bacteria, its activity depends on its chemical composition, chain length, and a number of sites of acetyl group in addition to the number of phosphate groups (David, 2001).

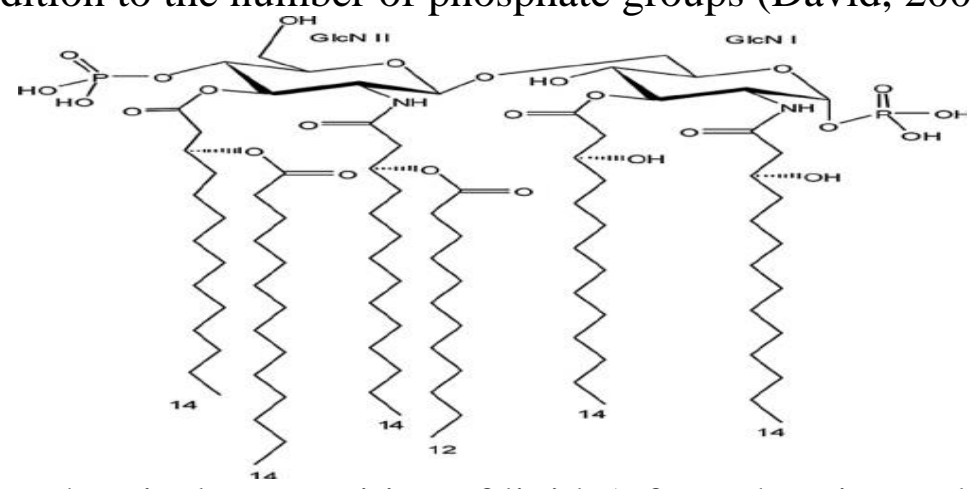

Figure (3): The chemical composition of lipid-A from the Lipo-polysaccharide of Escherichia coli (Silipo et al., 2010)

\section{1-8Metabolic pathways for the manufacture and transfer of Lipo- polysaccharides:}

The synthesis of LPS begins in the cytoplasm and goes through several consecutive polymerization processes until it reaches the final formula of its chemical composition. It's synthesis and metabolic pathways are among the characteristics of the Gram-negative bacteria. The synthesis process of it begins at the inner side of the plasma membrane and is carried out with the involvement of nine different enzymes, including enzymes LPXL, LPXC, LtdA, LPXK, LPXB, LPXH, LPXD, LPXC and LPXA,It begins to form Uridine diphosphate - diacyl-D-glucosamine (UDP - diacyl - GlcNAc) from Uridinediphoshat N-acetylglucosamine (UDP-GlcNAc) which is plays a key role in the biosynthesis of lipid-A in $R$. leguminosarum, different enzymes;

(i)UDP-GlcNAc3-O-acyltransferase;

(ii)UDP-3-O-(R-3-hydroxymyristoyl)-lcNAcdeacetylase;

(iii)UDP-3-O-(R-3-hydroxymyristoyl)-GlcNN-acyltransferase;

(iv) disaccharide synthase;

(v) 4'-kinase; and (vi) Kdo transferase (Price et al.,1994), that catalyze the early steps of $E$. coli lipid-A biosynthesis were also present in extracts of $R$. leguminosarum, and all these enzymes of the pathway leading to the formation of the intermediate 3- 
deoxy-D-manno-2-octulosonic acid ( $\left.\mathrm{Kdo}_{2}\right)$-lipid $\mathrm{IV}_{\mathrm{A}}$ are functional in both $R$. leguminosarum biovars phaseoli and viciae, thus giving the final $\mathrm{KDO}_{2}$-lipid-A by foure enzymes; 1-phosphatase, a mannosyl transferase, a galactosyl transferase, and a long chain acyl transferase, and three enzymes ;Lauroyl transferase (HtrB) ,Myristoyal transferase (MsbB) and Heptosyl transferase (RfaC), in $R$. leguminosarum and E.coli ,respectively, Fig.(4),( Brozek et al.,1996) .

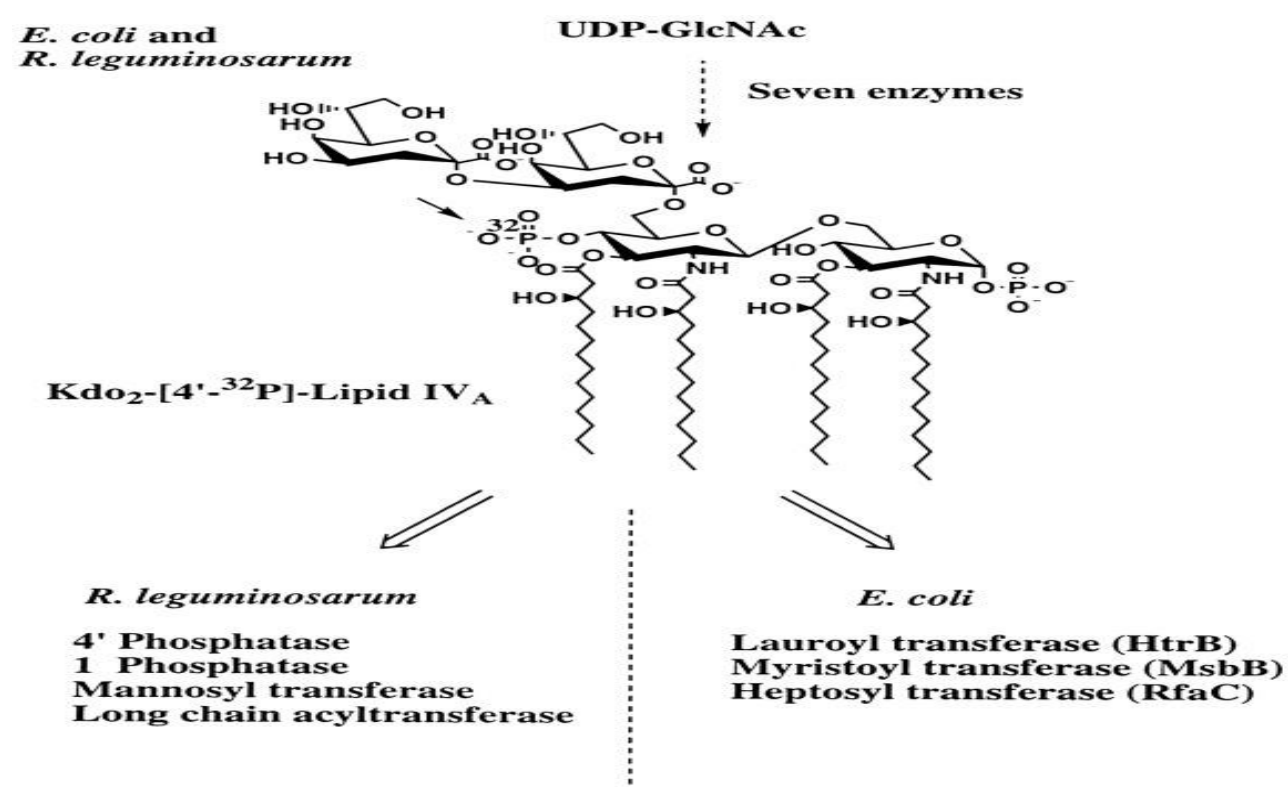

Figure: (4):Conserved biosynthesis followed by divergent processing of (Kdo) ${ }_{2}-$ lipid $\mathrm{IV}_{\mathrm{A}}$ inextracts of $R$. leguminosarum and E. coli. (Brozek et al.,1996) .

As shown in Figure (5), Lipid A, which is made in the cytoplasm and inner membrane, passes another stage by glycosyltransferases, where it joins the membrane with losing a sugar molecule to form Core Oligo-saccharides, which consists of 10-15 single sugar molecules, and then splits into two molecules to form Lipid-A and $\mathrm{O}$ antigen and thus the formation of lipo-polysaccharides(LPS),(Wang and Quinn,2010), to be transported through the cytoplasmic space between the two membranes to reach the outer membrane by many protein vectors such as LPTD, LPTG. LPtF, LPtc, LPtB, LPLA, LPtE(Sperando et al., 2007).Sometimes it may be required to send it back to the inner membrane to re-polymerize it if there is any deficiency in its components(Bos et al., 2004), this means that the LPS manufacturing process can be summed up in two paths: the first includes the formation of Lipid-A and the core, and the second includes the formation of the O-antigen(Wang and Quinn,2010).A large number of cluster genes located on the bacterium chromosome and its plasmids may participate in its synthesis, including the LPXD - Fabz - LPXA - LPXB Cluster genes, as the LPXB and LPXD gene group is split to manufacture $\mathrm{N}$-acyltransferases, which add fatty acids to the glucosamine compounds, while the LPXB gene encodes for the synthesis of disaccharide of Lipid-A from UDP -2-3 diacyl glucosamine, and the Fabz gene encodes for an enzyme that reduces the (3R)-hydroxyacyl-Acp complex to trans-2-acyl-Acp used as precursors of amino acids to manufacture phospholipids(Wang and Quinn, 2010). The Waa cluster genes encode to make several modifications to Lipid-A by adding an Mg component, and the Pmr A and 
Pmr B genes make modifications to LPS by adding Phospha ethanolamine(PETN) to the Core region of the LPS complex, and the operon D-gmh genes encode for building the synthesized LPS transporter proteins and link Polysaccharide to Lipid-A and the Core region(Gunn, 2008).The genes responsible for the synthesis of O-antigen were also classified, the first involved in the manufacture of internal sugars and involved in the synthesis of $\mathrm{O}$-antigen, the second stimulates the manufacture of primary sugars to form Oligosaccharid, and the third worked to terminate the process of manufacturing $\mathrm{O}$-antigen and its transmission through the membrane(Reeves and Wang, 2002), these genes encoding proteins active in these processes include the gulf and gnd genes and the genes encoding man B and C enzymes that convert mannose6-p into GDP-mannose(Ma et al., 2008).
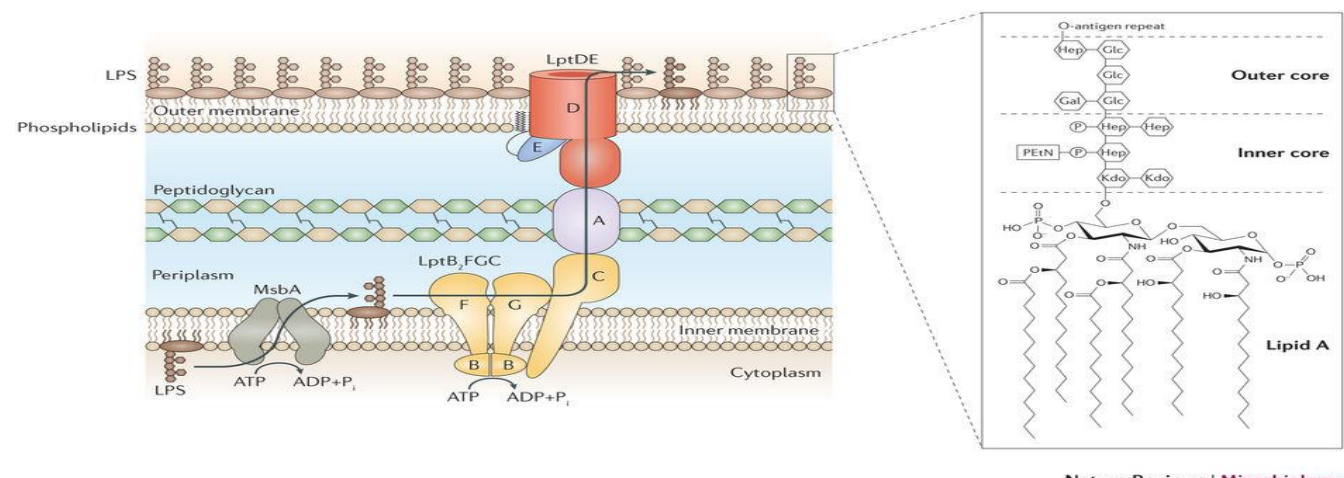

Figure.(5):Metabolic pathways for the manufacture and transport of LipoPolysaccharides(Schmid et al .,2015).

\section{1-9 Factors affecting the production of polysaccharides:}

The process of producing lipo-polysaccharides is affected by various factors, including the composition of the nutrient medium, and the Incubation conditions are of great importance in the growth of microorganisms and stimulating their production from lipo-polysaccharides and providing them with the necessary energy for the processes of biological construction (Duta et al., 2004), It is known that the main goal of changing the cultural conditions attempts to find out the factors affecting the increase and decrease in the productivity of Lipo-polysaccharides and to know the response of the bacteria to these changes, as more than one cultural factor may interfere to give the best response, and it is not possible to separate each factor affecting separately (Pinto et al., 2002). The most important factors affecting production are:

1-9-1 Strain variation: There are clear differences in the ability of bacterial isolates to produce multiplelipo-polysaccharides, as well as the quality of the product from a chemical and physical point of view, and this difference is mainly due to the strain of bacteria isolated from different cultural areas as each strain has properties that make it independent of the strains. The other, and this explains to us the conflicting and disparate results related to the production of polysaccharides when it comes to the different strains used in this research (Duta et al., 2004).

1-9-2 Culture component: The components of the culture media play an important role in the growth of microorganisms (Pinto et al., 2002), and affect the metabolites of these microorganisms, the most important of these components are: 
A- The carbon source: Carbohydrates are a general source of carbon, such as glucose, as it is used by micro-organisms more than any other sugar and is a general carbon source for them, as well as carbohydrates, are among the common sources used by microorganisms in the manufacture of polysaccharides. Since the production of multiple sugar and its quality depends on the carbon source used, which in turn affects the production(Basu and Ghosh,2001).However, if it does not produce all the basic intermediate compounds necessary for the synthesis process, it is not correct to use it to feed these micro-organisms as the only source of carbon (Pereira Duta et al., 2006), this is because the carbon element performs two important purposes for microorganisms. First, it is necessary to build essential compounds such as carbohydrates, proteins, lipids, and nucleic acids, and secondly, it is important in the process of carbon oxidation and provides a source of energy that is used to accomplish the biological processes of microorganisms (Al-Khafaji, 2008).It was found that the best medium for the production of LPS by that contains mannitol, sucrose, and glucose (Pereira Duta et al., 2006). Also, theconcentration of the carbonic source affects the efficiency of its transformation into multiple sugars. For example, the efficiency of the conversion of sucrose into a polymer by the rhizobium bacteria decreases with the increase in the concentrations of the carbonic source of sucrose(.Basu and Ghosh ,2001) pointed out that the different monosaccharides and disaccharides used in the production of the LPS from Rhizobium support its production in varying percentages.

B- Nitrogen source:Nitrogen constitutes about $8-14 \%$ of the dry weight of microorganisms and is included in the composition of their cellular components, especially amino acids, protein, nucleotides, some vitamins, and many enzymes necessary for the representation of these sugary compounds and other compounds (White, 2000). It also controls the production of microbial polysaccharides in liquid medium (Wenster-Botz,2000). Therefore, a source containing nitrogen must be available in the environment so that microorganisms can exploit it, and these sources play an important role in providing this element for use in building units. More than the role they play as energy sources, (Burgin et al., 2011). There is a wide range of organic and inorganic nitrogen sources that are used to meet the needs of the microorganism from nitrogen, and inorganic salts such as $\mathrm{NH}_{4}{ }^{+}$ and $\mathrm{NO}_{3}{ }^{-}$and organics such as amino acids, urea as well as non-synthetic sources of nitrogen such as yeast extract and casamino acid of milk.Among the most important nitrogen sources that are exploited by micro-organisms in the production of polysaccharides are ammonia salts, amino acids, nitrates, and nitrogen gas. The first and second sources are among the most used nitrogen sources in cultural circles, but they must be added in balanced proportions because increasing the concentration of these sources stops the ability of bacteria to produce multiple sugars on despite its stimulatory effect on increasing bacterial growth (Wenster-Botz, 2000).

C- Inorganic nutrient: Despite the availability of energy sources, carbon, and nitrogen for the microbial cell, it cannot grow in the absence of mineral elements (Duta et al., 2004). Therefore, its presence in food circles, in general, is necessary for the growth of micro-organisms as well as for the production of various metabolic materials, whether primary or secondary metabolites, as they act as a 
catalyst for some enzymes that play an important role in the metabolic processes, and play an important role in controlling cell membrane permeability, including the transfer of energy sources, so the presence of some positive ions such as potassium, magnesium, iron, and calcium in the culture media is necessary to give an ideal growth. On the other hand, the micro-organisms need negative ions such as $\mathrm{Cl}^{-}$which may act as a catalyst for some enzymes involved in the metabolic processes or it may play an important role in the permeability of the cell membrane and the transmission of energy sources. However, these elements may be bidirectional, as increasing concentration to an optimal level inhibits production (Al-Khafaji, 2008). Inorganic nutrients include:

1. Phosphorous: living cells, including bacteria, need phosphorous, which plays an important role in metabolism and other vital activities. Phosphorous is included in high-energy compounds such as ATP, GTP and others. It is also used in the synthesis of fats containing phosphorous and acids. (Al-Khafaji, 2008).Xu et al., (2012) also studied the effect of phosphorus deficiency on cyclic (12) gluconate in Agrobacterium tumefaciens, and they was found that this leads to a loss of the bacteria's ability to convert the phosphoglycerol compensator into $\beta(1 \rightarrow 2)$ Cyclic, One of the studies(Rehm,2010) hasindicated the possibility of using phosphorous to form $\mathrm{KH}_{2} \mathrm{PO}_{4}$ and he concluded from this study that phosphorus is an important factor in the production of polymers in microorganisms.

2. Magnesium: It is an important inorganic nutrient that micro-organisms need in adequate quantities. Important cell components such as the membranes and cell walls of bacteria, as well as help in the synthesis of ribosomes (Al-Khafaji, 2008).

3. Sulfur: It is one of the important minerals that microorganisms need to produce polysaccharides. The role that sulfur plays in microorganisms is more than the role it plays for the rest of the cell types. Sulfur enters in the synthesis of amino acids such as cysteine, cystine, and methionine (Martin et al., 2011). It may be one of the important elements that micro-organisms need to carry out various metabolic activities, and ammonium sulfate $\left(\mathrm{NH}_{4}\right)_{2} \mathrm{SO}_{4}$, which is used as a nitrogen source, represents the usual source of sulfur that is used by microorganisms in agricultural media prepared to produce various compounds. Al-Khafaji (2008) indicated that sulfur is found in some types of vitamins such as thymine, biotin, and pyridoxine.

4. Potassium: It is entered as a companion to some enzymes as it helps in stimulating growth and the cell needs in the synthesis of carbohydrates and the transport stages (Etesami et al., 2017). Potassium ions may be added, usually in an inorganic form, in the form of $\left(\mathrm{K}_{2} \mathrm{HPO}_{4}\right.$ or $\left.\mathrm{KH}_{2} \mathrm{PO}_{4}\right)$ to the prepared nutrient media to develop some types of microorganisms.

D- Elements and other factors: The micro-organisms in their own culture media need to add growth factors as these substances stimulate the growth of microorganisms. The growth factors to include the groups: vitamins, amino acids, nitrogenous bases, and other factors such as some types of alcohols (ethanol, methanol) or fats, fatty acids and some types of plant hormones. These compounds are used in very low concentrations in nutrient media to stimulate the growth of micro-organisms and produce important compounds such as citric acid, antibiotics, and polysaccharides (Al-Khafaji, 2008). Yeast extract is added to the 
food media preparation for the growth of micro-organisms and the production of polysaccharides as one of the compounds containing various growth factors and vitamins to stimulate the production of polysaccharides by micro-organisms (Hakobyan, et al., 2012).

E- pH value: The $\mathrm{pH}$ is one of the important factors in the production of polysaccharides. During the subsequent stages of fermentation of polysaccharides, it was observed that the concentration of hydrogen ion decreases due to the formation of polymers and organic and inorganic acids, where research indicates the role of $\mathrm{pH}$ in influencing the growth of micro-organisms and its production from primary or secondary metabolites, in particular extracellular polysaccharides. Duta et al., (2004) explained the effect of the $\mathrm{pH}$ on the growth of micro-organisms and stated that multiple factors change the $\mathrm{pH}$ during biological processes, including acid-producing components and some types of nutrients, as well as oxidation and reduction reactions and changes in neutral nutrient solutions, he also showed that the effect of the $\mathrm{pH}$ in the production of polysaccharide is more than its effect on the growth of micro-organisms, and explained its effect on the permeability of cells and the nature of the vital activities that occur in the cell. The hydrogen ion concentration and its fall between (6.0$7.5)$ is very important in the process of building commercial polysaccharides of bacteria (Gorret et al., 2001), and the rise or fall of the final $\mathrm{pH}$ of the fermentation medium depends on the type of bacterial strain and the composition of the culture medium.

\section{5- Physical Properties of Lipo-polysaccharides:}

5-1Viscosity: The polysaccharide microbial solutions are characterized by their vicious nature, as their viscosity varies according to the type of the microorganism producing the polysaccharide and even with the different strains of the same type,and this viscosity is one of the main parameters determining the rheological properties of this compound(Moretto et al., 2015). Poise is used to express the viscosity relative to the world Poiseuille, and it is defined as the force estimated in the unit of one dian, sufficient to move a flat surface of an area of 1 $\mathrm{cm}^{2}$ away from a distance of $1 \mathrm{~cm}$ from another surface similar to it, which gives acceleration to the moving surface of $1 \mathrm{~cm} / \mathrm{second}$, the viscosity of multiple sugars depends on several factors including the components of the culture medium, the source and concentration of the elements of carbon and nitrogen, mineral salts and fermentation conditions such as $\mathrm{pH}$, oxygen concentration and the degree of product movement (Duta et al., 2004). The viscosity of this compound was measured by Al-Zuhairi (2002) by preparing aqueous solutions from (LPS) and measuring it with a viscometer, which ranged between0.0020 - 0.0033 (dyne. $\left.\mathrm{Sec} / \mathrm{cm}^{2}\right)$.

5-2 Specific optical rotation:Optical rotation is one of the common physical characteristics of polysaccharides and this characteristic varies according to the type of polysaccharide. Where sugars are considered optically active substances and are distinguished by the special rotation of the level of polarized light circularly to the right, as in the case of $\alpha$-glucan,and this compound is called dextrorotatory, so is given the symbol ( + or D), while the left-spinning compound is called Levorotatory, as in the case of $\beta$-glucan, and it is symbolized by it (- or 
L). The phase difference between the waves of polarized light circularly to the left or right lead to the rotation of the level of polarization of the light passing through the sugar solution, and it varies according to the type of sugar, it is usually symbolized by it $[\mathrm{a}]^{\mathrm{D}_{20}}$ where (a) represents the degree of optical rotation and (D) represents the wavelength (Al-Fleih,2000). The optical rotation of the lipopolysaccharides produced from the rhizobium bacteria is performed to detect the active groups using the infrared ray of the IR device (Al-Zuhairi, 2002), this assay is used to detect that the LPS compound contains the carbonyl group, the ester group, and the $\mathrm{OH}$ hydroxyl group, respectively.

\section{6-LPS and its role in the symbiotic relationship between Rhizobium and leguminous plants}

The LPS compound plays an important role in the success of the symbiotic relationship between Rhizobium bacteria and leguminous plants, as these compounds consist of (4-5) repeated units of glucosamine tetra or penta Emeric N-acetyl glucosamine (GlcNAc) to form a two-ended chain, the first end is reduced, bearing compensators specific to the rhizobia species are important for forming root nodules on leguminous plants specialized in their infection, and they may be either in the form of N-acetyl-glucosyl or in the form of a sulfate group(Broughton et al., 2000).The second non-reducing end holds the fatty acid chain at carbon atom No. 2 and the acety 1 group at carbon atom No. 6 of the Glucosamine molecule (Cullimore et al., 2001).Nodulation (Nod) factors are produced by two types of genes: the common genes and host -specificnod genes. The common genes nodABCM are found in all types of rhizobia. Together, by the enzyme $\mathrm{N}$-acetyl glucosamine 1 transferase encoded by the $o d c$ gene, to build the chitin portion (UDP - N-acetylglucosamine) which is the backbone of the compounds of nodule-forming factors(René and Ton ,2002).The nodA and $\operatorname{nod} B$ genes are responsible for the transfer of the Acuity 1 group and the fatty acyl chain into the free amine group that extends at the non-reducing endpoint, respectively (Galibert et al, 2001), while the host-specific genes, including the nodLgene, encoding to build acetyl group, while nodFE genes encode to build the unsaturated fatty acyl chain at the non-reducing end of the $\mathrm{N}$-acetylglucosamine (GlcNAc) chain (Geurts, and Bisseling,2002).Fatty acids differ in the number of saturated and unsaturated carbon atoms that form them according to the type of rhizobia bacteria. In Ensifer meliloti bacteria, it consists of 16 carbon atoms, two of which are unsaturated (16: 2), while in R. Leguminosarium bv. viciae consists of 18 carbon atoms, one of which may be saturated and four unsaturated (18: 1, 18:4), and in Mezorhizobium loti bacteria, this chain is made of 18 carbon atoms, one of which is saturated (18:1), (Diaz et al.,2000). The other genes, the nod $H P Q$ genes that are also specialized in the host, encode the production of specialized compensators located on the carbon atom No. 6 of the glucose amine molecule at the reduced end of the GlcNAc chain (Keatling et al., 2002). Nodulation factors agents are associated with recipients located on the root hairs of plasma membrane(Cullimore et al., 2001), two types of them (NFBS1 and NFBS2) were distinguished in both Medicago and Phaseolus beans, the first site having little interest in binding and not having any role in the symbiotic relationship, and the second site with high affinity for binding to the fatty acyl chain present in the nodulation factors and had an important role in the success of the specialized symbiotic relationship as well as, the known role of these 
factors in the deformation of the root hairs and the occurrence of divisions of cells of the cortex infected with bacteria to form the primary nodules called primordium nodules(Perret et al., 2000).

\section{7-The role of lipopolysaccharides (LPS) in tissue culture of plants:}

Many of the studies indicated that the LPS compound consisting of (4-6) sugar units has a positive effect in stimulating cell division more effectively than the compound consisting of less than 4 units of monosaccharide, and the first evidence of its effectiveness has indicated that it is directly responsible for abnormal growth and development of somatic embryos in plant pieces of Medicago sativa(Hoori et al., 2007). As well as its ability to induce plant pieces of Pimpinella anisum seedlings to divide and create and differentiate callus from it alone or in combination with growth regulators (AL-Barhawi and AL-Zaidy,2020), while other studies have indicated the importance of the lipo-polysaccharides isolated from Ensifer meliloti bacteria and added to solid MS medium, in callus formation from hairy roots cultures formed on M. sativa by infection with Agrobacterium rhizogenes R1601 (Habash, 2002), and in this context Al-Zuhairi (2002) succeeded in isolating callus from pieces of stems and root of Trifolium repens when supplementing Murashige and Skoog medium(MS)with concentrations (4 and 6) $\mathrm{mg} / \mathrm{L}$ of lipo-polysaccharides isolated from Rhizobium leguminosarium biovar trifolii.

The study conducted by (Al-Qusaymy, 2006) indicated a high rate of nodule numbers and a high protein content of $S$. meliloti-infected seedlingsMedicago sativa, the tops of the root hairs swelled and the protoplast was released from them when grown this seedlings on NFree medium (NF) supplemented with LPS compound, and the growth rates increased of callus for pieces plant grown on MS medium supported with interfering concentrations of 1-Naphthaleneacetic acid (NAA) and LPS, and formation of green-colored callus, due to the development of stems of fenugreek seedlings on the surface of solid MS medium supported by growth regulator NAA and LPS extracted from this bacteria as well.It was also observed that LPS extracted from Ensifer melilotiand Rhizobium leguminosarum bv. trifolii when added to solid NF medium had a stimulating role represented by the formation of nodules-like structures free of atmospheric nitrogen-fixing bacteria on the roots of the Medicago sativa and Trifollum repens seedlings specialized in infecting them (Gressent et al., 2002). By following up the effect of nodulation factors known as lipo-polysaccharides isolated from this bacterium(Rhizoium sp.) on cell divisions in cell suspension cultures of legume plants, and in the field of identifying the effect of Lipid-A fatty acid extracted from LPS ofEnsifer meliloti, notedit has a Stimulatingeffect on cell division from cell suspension cultures of alfalfa plants (Scheidle et al., 2005) and on obtaining secondary metabolites and saponin steroids such as diosgenin from fenugreek( AL-Zubaidi, 2004).

\section{8-Immuno-modulatory effects of Lipo-polysaccharides:}

Lipo-polysaccharides is polycystic one of the many components present on the surface of bacterial cells, which has the ability to prevent the devouring of bacteria by specialized antibodies to them, and is responsible for the formation of infection shock, so it is a major target in treatment strategies against infection with pathogenic bacteria producing it. Endotoxins derived from different bacterial species share a common basic structure(Pulendran et al., 2001; Todar, 2002).The Lipo- 
polysaccharides isolated from bacteria, especially Escherichia coli, are one of the endotoxins that have a role in the vitality and virulence of the bacteria (Nagao et al., 2001 and Pulendran et al., 2001).The biological activity of endotoxins is usually related to the Lipo-polysaccharide, while the Toxic activity of the Lipopolysaccharide is related to the lipid-A. The immune activity is related to the components of the multiple sugars. The cell wall antigens ( $\mathrm{O}$ antigens) of Gramnegative bacteria are actually components of the LPS, so it induces different inflammatory responses inside the host, and it is located on the outer sides of the membrane where contact with the external environment and the LPS is necessary for the function of the outer membrane as one of the components of the cell, and it may play many roles in the pathogenesis of Gram-negative bacteria by preventing it from bile salts from penetrating the bacteria or any other toxic particles in the gastrointestinal tract,LPS also acts as a hindrance to hemolytic enzymes and antibacterial agents. Besides, it prevents bacterial cell breakdown using serum components and macrophages. It is plays an important role as a surface compound in the interaction of the pathogen with its host, as it may be related to adhesion (colony formation), resistance to phagocytosis, or antigenic changes that determine the duration and outcome of infection(Todar, 2002).

LPS is a strong stimulator of natural immunity in its host because it increases the cellular immune response (Yaseen, 2009), so it is an immunomodulator for both humoral and cellular immunity, and this property plays a role in the growth and development of the chronic immune response to treating micro-organisms. It also stimulates, especially the extract from E. coli bacteria, dendritic cell groups, and $\mathrm{T}$ cells to produce different cytokines and induce acquired immunity(Pulendran et al., 2001).It also stimulates monocytes and macrophages to produce cytokines, including interleukin 8, 6, and 1 , which is the cancer necrosis factor and platelet-activating agent, and at the same time it stimulates macrophage cells to promote macrophage and cytotoxicity by stimulating them to produce and release enzymes such as cytokines and release interleukin 1 causes fever. The Lipo-polysaccharide activates the complement chain, especially $\mathrm{C}_{5} \mathrm{a}$ and $\mathrm{C}_{3} \mathrm{a}$, which release histamine leading to vasodilation, as well as lead to the chemical attraction of the neutrophil cells that result in inflammation. This compound also activates the clotting chain that results in internal bleeding and the ultimate effect is to stimulate inflammation, intravascular thrombosis, hemorrhage, and shock(Todar, 2002).The LPS activates beta cell to produce polyclonal antibodies, and multiply the (B) cells to produce the immunoglobulins $\operatorname{IgG}$ and $\operatorname{IgM}$, noting that the physiological effects of LPS are caused by Lipid-A (Nagao et al., 2001), there are different reductive types of reactions in the host called endotoxin-toxic activities including fever, hypotension, internal organ failure, and in standard cases haematological shock and vascular thrombosis through interaction with humoral and cellular factors of mammalian hosts and high concentrations of this toxin to prepare cells of inflammatory vascular systems (Abd and Abdul-Hameed,2012).

\section{CONCLUSION}

The difference in Gram-negative bacteria, especially Rhizobium bacteria, at the level of species and strain, is due to their difference in terms of chemical composition 
and biological effects of the Lipo-polysaccharides that these bacteria contain, in stimulating the formation of pseudo-root nodules without bacteria, as well as, stimulating the cells of plant pieces plant to division and production callus under laboratory condition, and we hope in the coming years to discover its positive and security effect on human life, given that these bacteria are non-pathogenic sympathetic species for living organisms, especially humans.

$$
\begin{aligned}
& \text { الفعالية البايولوجية لعديد السكريات الدهنية في بكتربا الرايزوبيوم }
\end{aligned}
$$

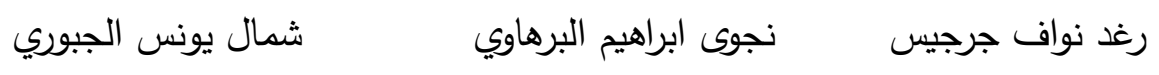

$$
\begin{aligned}
& \text { قسم علوم الحياة /كلية التربية للعلوم الصرفة / جامعة الموصل } \\
& \text { Email: raghadnawaf@uomosul.edu.iq }
\end{aligned}
$$

\begin{abstract}
الخلاصة
تعد السكريات المتعددة الدهنية من المواد الحيوية المهمة والتي تتألفغالباً من ثلاثة مكونات أساسية هي LipidA: تثـفر من قبل جينات خاصـة تسـى بالجينات العنقودية Cluster genes، وتتميز هذه السكريات بالعديد من

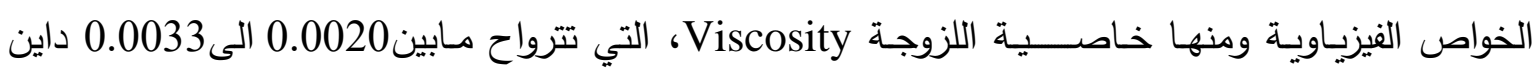

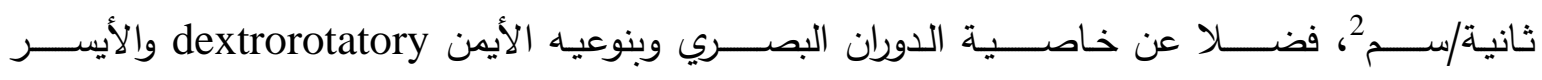

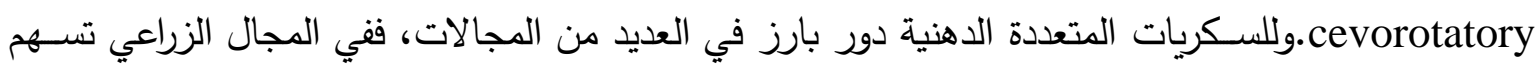
في تكوين العقد الجذرية على النباتات البقولية ذات الأهمية الكبيرة في عمليات تثبيث النتروجين الجوي وزيادة المحتوى البروتيني للنباتات البقولية، فضـــلاً عن دورها في عمليات اســتحداث وتمايز كالس النباتات البقولية كالجت والبرسـيم وغير البقولية مثل التبخ. أما في المجال الطبي والصـيدلاني فلها أهمية واضـحة في عمليات الاستجابة المناعية من خلال وجودها كأحد المستضدات المهمة الموجودة على أسطح الخلايا البكتيرية،فضـلاً عن دورها في عملية الالتصــاق المؤدية لتكوين المسـتعمرات البكتيرية وكحواجز تمنع نفاذ العوامل المضــادة لاخل الخلية البكتيرية.
\end{abstract}

الكلمات المفتاحية: Rhizobiumm, Lipopolysaccharide, Lipid-A, Core regin, O-antigen تاريخ تسلم البحث: 2021/1/3، وقبوله: 2021/3/29

\title{
REFERENCES
}

Abd, G. S. \& Abdul-Hameed,B.H. (2012).Effect of lipopolysaccharide on the liver function test. Al-Anbar Journal Veterinary Science, 5(1),56-161.

AL-Barhawi, N. I., \& AL-Zaidy,R.N. (2020). The effect of lipo-polysaccharide isolated from Sinorhizobium meliloti bacteria on the tissue culture of Pimpinella anisum plants.Journal of Xi'an University of Architecture \& Technology, 12,1006-7930. 
Al-Fleih, K.A. (2000). Introduction to Biochemistry. Second edition, Book House for Printing and Publishing, Mosul University, Iraq.P:520.

Al-Khafaji, Z. M. (2008). Microbial Biotechnology (molecular approaches). Institute for Genetic Studies and Biotechnology for Postgraduate Studies, University of Baghdad, Ministry of Higher Education and Scientific Research, Iraq.P:312.

Al-Qusaymy, A. H. S. (2006).Biological Activity of lpopolysaccharide Etracted from Sinorhizobium meliloti on Root Nodules Formation, Initiation of Callus and Cell Suspension Divition of Trigonella foenum-graecurnfoenum-graecurn Seedlings .M.Sc.Thesis, College of Education, University of Mosul,Iraq.P:78.

Al-Zubaidi, L. T. S. (2004). Quantification of Diosgenin Compound in Callus, cellular suspensions, and capillary roots of Trigonella foenum-graecurn, using high-Efficiency Liquid Tomography Technology. M.Sc. Thesis, Faculty of Education, University of Mosul, Iraq.P:122.

Al-Zuhairi, O. A. A. (2002). Evidence of Family Specialization and Transformation, Between Genetically Engineered White Clover, Rhizobium bacterium, and Genetically Engineered Agrobacterium. M.Sc. Thesis, College of Education, University of Mosul, Iraq.P:126.

Amor, K., Heinrichs, D. E., Frirdich, E., Ziebell, K., Johnson, R. P., \& Whitfield, C. (2000). Distribution of core oligosaccharide types in lipopolysaccharides from Escherichia coli. Infection and immunity, 68 (3), 1116-1124.

Basu, P. S., \& Ghosh, A. C. (2001). Production of indole acetic acid in culture by a Rhizobium species from the root nodules of a monocotyledonous tree, Roystonea regia. Acta biotechnologica, 21(1), 65-72.

Bos, M. P., Tefsen, B., Geurtsen, J., \& Tommassen, J. (2004). Identification of an outer membrane protein required for the transport of lipopolysaccharide to the bacterial cell surface. Proceedings of the National Academy of Sciences, 101(25), 9417-9422.

Broughton, W. J., Jabbouri, S., \& Perret, X. (2000). Keys to symbiotic harmony. Journal of bacteriology, 182(20), 5641-5652.

Brozek, K. A., Kadrmas, J. L., \& Raetz, C. H. (1996). Lipopolysaccharide biosynthesis in Rhizobium leguminosarum: novel enzymes that process precursors containing 3-deoxy-D-manno-octulosonic acid. Journal of Biological Chemistry, 271(50), 32112-32118.

Burgin, A. J., Yang, W. H., Hamilton, S. K., \& Silver, W. L. (2011). Beyond carbon and nitrogen: how the microbial energy economy couples elemental cycles in diverse ecosystems. Frontiers in Ecology and the Environment, 9(1), 44-52.

Campbell, G. R., Reuhs, B. L., \& Walker, G. C. (2002). Chronic intracellular infection of alfalfa nodules by Sinorhizobium meliloti requires correct lipopolysaccharide core. Proceedings of the National Academy of Sciences, 99(6), 3938-3943.

Cullimore, J. V., Ranjeva, R., \& Bono, J. J. (2001). Perception of lipochitooligosaccharidic Nod factors in legumes. Trends in plant science, 6(1), 24-30.

D'Antuono, A. L., Casabuono, A., Couto, A., Ugalde, R. A., \& Lepek, V. C. (2005). Nodule development induced by Mesorhizobium loti mutant strains affected 
in polysaccharide synthesis. Molecular plant-microbe interactions, 18(5), 446-457.

David, S. A. (2001). Towards a rational development of anti-endotoxin agents: novel approaches to sequestration of bacterial endotoxin with small molecules. Journal of Molecular Recognition, 14(6), 370-387.

Díaz, C. L., Spaink, H. P., \& Kijne, J. W. (2000). Heterologous rhizobial lipochitin oligosaccharides and chitin oligomers induce cortical cell divisions in red clover roots, transformed with the pea lectin gene. Molecular Plant-Microbe Interactions, 13(3), 268-276.

Duta, F. P., De França, F. P., Sérvulo, E. F. C., Lopes, L. M. D. A., Da Costa, A. C. A., \& Barros, A. (2004). Effect of Process Parameters on Production of a Biopolymer by Rhizobium sp. In Proceedings of the Twenty-Fifth Symposium on Biotechnology for Fuels and Chemicals Held May 4-7, 2003, in Breckenridge, CO (pp. 639-652). Humana Press, Totowa, NJ.

Etesami, H., Emami, S., \& Alikhani, H. A. (2017). Potassium solubilizing bacteria (KSB):: Mechanisms, promotion of plant growth, and future prospects A review. Journal of soil science and plant nutrition, 17(4), 897-911.

Fraysse, N., Couderc, F., \& Poinsot, V. (2003). Surface polysaccharide involvement in establishing the rhizobium-legume symbiosis. European Journal of Biochemistry, 270(7), 1365-1380.

Fraysse, N., Lindner, B., Kaczynski, Z., Sharypova, L., Holst, O., Niehaus, K., \& Poinsot, V. (2005). Sinorhizobium meliloti strain 1021 produces a lowmolecular-mass capsular polysaccharide that is a homopolymer of 3-deoxy-Dmanno-oct-2-ulosonic acid harboring a phospholipid anchor. Glycobiology, 15(1), 101-108.

Galibert, F., Finan, T. M., Long, S. R., Pühler, A., Abola, P., Ampe, F., ... \& Batut, J. (2001). The composite genome of the legume symbiont Sinorhizobium meliloti. Science, 293(5530), 668-672.

Geurts, R., \& Bisseling, T. (2002). Rhizobium Nod factor perception and signalling. The Plant Cell, 14(suppl 1), S239-S249.

Gorret, N., Maubois, J. L., Engasser, J. M., \& Ghoul, M. (2001). Study of the effects of temperature, $\mathrm{pH}$ and yeast extract on growth and exopolysaccharides production by propionibacterium acidi-propionici on milk microfiltrate using a response surface methodology. Journal of Applied Microbiology, 90(5), 788-796.

Gressent, F., Mantegazza, N., Cullimore, J. V., Driguez, H., Ranjeva, R., \& Bono, J. J. (2002). High-affinity Nod factor binding site from Phaseolus vulgaris cell suspension cultures. Molecular plant-microbe interactions, 15(8), 834-839.

Gunn, J. S. (2008). The Salmonella PmrAB regulon: lipopolysaccharide modifications, antimicrobial peptide resistance and more. Trends in microbiology, 16(6), 284-290.

Habash, A. Y. J (2002).Stimulation and Genetic Transformation by Agrobacterium rhizogenes $\mathrm{R} 1601$ in Improvement of Protein Content in Alfalfa and Clover Plants. M.Sc.Thesis, College of Education, University of Mosul, Iraq.P:95.

Hakobyan, L., Gabrielyan, L., \& Trchounian, A. (2012). Yeast extract as an effective nitrogen source stimulating cell growth and enhancing hydrogen 
photoproduction by Rhodobacter sphaeroides strains from mineral springs. international journal of hydrogen energy, 37(8), 6519-6526.

Hoori, F., Ehsanpour, A. A., \& Mostajeran, A. (2007). Comparison of somatic embryogenesis in Medicago sativa and Medicago truncatula. Pakistan journal of biological sciences: PJBS, 10(3), 481-485.

Kato, N., Sugiyama, T., Naito, S., Arakawa, Y., Ito, H., Kido, N., ... \& Sasaki, K. (2000). Molecular structure of bacterial endotoxin (Escherichia coli Re lipopolysaccharide): implications for formation of a novel heterogeneous lattice structure. Molecular microbiology, 36(4), 796-805.

Keating, D. H., Willits, M. G., \& Long, S. R. (2002). A Sinorhizobium meliloti lipopolysaccharide mutant altered in cell surface sulfation. Journal of bacteriology, 184(23), 6681-6689.

Kilár, A., Dörnyei, Á., \& Kocsis, B. (2013). Structural characterization of bacterial lipopolysaccharides with mass spectrometry and on-and off-line separation techniques. Mass spectrometry reviews, 32(2), 90-117.

Laverty, G., Gorman, S. P., \& Gilmore, B. F. (2014). Biomolecular mechanisms of Pseudomonas aeruginosa and Escherichia coli biofilm formation. Pathogens, 3(3), 596-632.

Lepek, V. C., \& D'Antuono, A. L. (2005). Bacterial surface polysaccharides and their role in the rhizobia-legume association. Lotus Newslett, 35, 93-105.

Lerouge, I., \& Vanderleyden, J. (2002). O-antigen structural variation: mechanisms and possible roles in animal/plant-microbe interactions. FEMS microbiology reviews, 26(1), 17-47.

Ma, B., Reynolds, C. M., \& Raetz, C. R. (2008). Periplasmic orientation of nascent lipid $\mathrm{A}$ in the inner membrane of an Escherichia coli LptA mutant. Proceedings of the National Academy of Sciences, 105(37), 1382313828.

Moreira, L. M., Becker, J. D., Pühler, A., \& Becker, A. (2000). The Sinorhizobium meliloti ExpE1 protein secreted by a type I secretion system involving ExpD1 and ExpD2 is required for biosynthesis or secretion of the exopolysaccharide galactoglucan. Microbiology, 146(9), 2237-2248.

Moretto, C., Castellane, T. C. L., Lopes, E. M., Omori, W. P., Sacco, L. P., \& de Macedo Lemos, E. G. (2015). Chemical and rheological properties of exopolysaccharides produced by four isolates of rhizobia. International journal of biological macromolecules, 81, 291-298.

Nagao, A. T., Friedlander-Del Nero, D., Arslanian, C., \& Carneiro-Sampaio, M. M. S. (2001). Elevated levels and different repertoire profile of colostral anti-LPS antibodies may have a significant role in compensating newborn immunity. Scandinavian Journal of Immunology, 53(6), 602-609.

Noel, K. D., \& Duelli, D. M. (2000). Rhizobium lipopolysaccharide and its role in symbiosis. Prokaryotic nitrogen fixation: a model system for the analysis of a biological process., 415-431.

Pereira Duta, F., Pessôa de França, F., \& de Almeida Lopes, L. M. (2006). Optimization of culture conditions for exopolysaccharides production in Rhizobium sp. using the response surface method. Electronic Journal of Biotechnology, 9(4), 391-399. 
Perret, X., Staehelin, C., \& Broughton, W. J. (2000). Molecular basis of symbiotic promiscuity. Microbiology and Molecular Biology Reviews, 64(1), 180-201.

Pinto, E., Moreira, A., \& Vendruscolo, C. T. (2002). Influence of pH, addition of salts and temperature in the viscosity of biopolimers produced by Beijerinckia sp. 7070 and UR4. Revista Brasileira de Agrociência, 8(3), 247-251.

Price, N. P., Kelly, T. M., Raetz, C. R., \& Carlson, R. W. (1994). Biosynthesis of a structurally novel lipid A in Rhizobium leguminosarum: identification and characterization of six metabolic steps leading from UDP-GlcNAc to 3-deoxyD-manno-2-octulosonic acid2-lipid IVA. Journal of bacteriology, 176(15), 4646-4655.

Pulendran, B., Kumar, P., Cutler, C. W., Mohamadzadeh, M., Van Dyke, T., \& Banchereau, J. (2001). Lipopolysaccharides from distinct pathogens induce different classes of immune responses in vivo. The Journal of Immunology, 167(9), 5067-5076.

Raetz, C. R., \& Whitfield, C. (2002). Lipopolysaccharide endotoxins. Annual review of biochemistry, 71(1), 635-700.

Reeves, P. P., \& Wang, L. (2002). Genomic organization of LPS-specific loci. Pathogenicity islands and the evolution of pathogenic microbes, 109135.

Rehm, B. H. (2010). Bacterial polymers: biosynthesis, modifications and applications. Nature Reviews Microbiology, 8(8), 578-592.

Rittig, M. G., Kaufmann, A., Robins, A., Shaw, B., Sprenger, H., Gemsa, D., ... \& Dornand, J. (2003). Smooth and rough lipopolysaccharide phenotypes of Brucella induce different intracellular trafficking and cytokine/chemokine release in human monocytes. Journal of leukocyte biology, 74(6), 1045-1055.

Sachdeva, S., Palur, R. V., Sudhakar, K. U., \& Rathinavelan, T. (2017). E. coli group 1 capsular polysaccharide exportation nanomachinary as a plausible antivirulence target in the perspective of emerging antimicrobial resistance. Frontiers in microbiology, 8,1-19.

Scheidle, H., Groß, A., \& Niehaus, K. (2005). The lipid A substructure of the Sinorhizobium meliloti lipopolysaccharides is sufficient to suppress the oxidative burst in host plants. New phytologist, 165(2), 559-566.

Schmid, J., Sieber, V., \& Rehm, B. (2015). Bacterial exopolysaccharides: biosynthesis pathways and engineering strategies. Frontiers in microbiology, 6,1-24.

Serrato, R. V. (2014). Lipopolysaccharides in diazotrophic bacteria. Frontiers in cellular and infection microbiology, 4, 119.

Silipo, A., Erbs, G., Shinya, T., Dow, J. M., Parrilli, M., Lanzetta, R., ... \& Molinaro, A. (2010). Glyco-conjugates as elicitors or suppressors of plant innate immunity. Glycobiology, 20(4), 406-419.

Spaink, H. P. (2000). Root nodulation and infection factors produced by rhizobial bacteria. Annual Reviews in Microbiology, 54(1), 257-288.

Sperandeo, P., Cescutti, R., Villa, R., Di Benedetto, C., Candia, D., Dehò, G., \& Polissi, A. (2007). Characterization of lptA and lptB, two essential genes implicated in lipopolysaccharide transport to the outer membrane of Escherichia coli. Journal of bacteriology, 189(1), 244-253. 
Tang, G., Wang, Y., \& Luo, L. (2014). Transcriptional regulator LsrB of Sinorhizobium meliloti positively regulates the expression of genes involved in lipopolysaccharide biosynthesis. Applied and environmental microbiology, 80(17), 5265-5273.

Todar, K. (2002). Mechanisms of Bacterial Pathogenicity. University of Wisconsin, Madison, Wisconsin, http://textbookofbacteriology. net/endotoxin. html.

Wang, X., \& Quinn, P. J. (2010). Lipopolysaccharide: biosynthetic pathway and structure modification. Progress in lipid research, 49(2), 97-107.

Weuster-Botz, D. (2000). Experimental design for fermentation media development: statistical design or global random search?. Journal of bioscience and bioengineering, 90(5), 473-483.

White, D. (2000). Physiology and Biochemistry of Prokaryotes. Oxford University Press.

Xu, J., Kim, J., Danhorn, T., Merritt, P. M., \& Fuqua, C. (2012). Phosphorus limitation increases attachment in Agrobacterium tumefaciens and reveals a conditional functional redundancy in adhesin biosynthesis. Research in microbiology, 163(9-10), 674-684.

Yaseen, I. M. (2009). Congenital immunity modulation in toxoplasmosis using lipopolysaccharide of Escherichia coli. Tikrit Journal of Pure Science, 14(2), 238-244. 